\title{
Terapia de Casais. Uma visão Junguiana
}

Nairo de Souza Vargas, Madras Editora, São Paulo, 2004

Prof. Dr. Zacaria Borge

Ali RAMADAM ${ }^{1}$
O casamento como início e base da família, onde nascemos e fundamentalmente nos formamos, é tema da maior importância para a psicologia. O livro trata da terapia de casais embasada na teoria da Psicologia Analítica de Jung.

O autor, por suas características, história de vida e formação, há muitos anos dedica-se ao trabalho psicoterápico com casais.

O livro apresenta, na sua primeira parte, uma história dessa forma de terapia, desde seus primórdios, e, dentro do assunto "Casamento e o Terapeuta", aborda também os temas: Verdadeiro Casamento, A Escolha do Terapeuta, A Função do Terapeuta e Formas de Atendimento Conjugal.

A visão do ser humano pela Psicologia Analítica é o enfoque da segunda parte, em que são descritos os referenciais teóricos nos quais baseia seu trabalho psicoterapêutico. $\mathrm{O}$ autor, por meio de metodologia de pesquisa qualitativa de estudo de caso, propõe-se a estudar os vínculos de casal, através da psicoterapia desses casais.

Como maneira prática e clinicamente útil para lidar com casais com dificuldades, propõe a visão do casamento como um possível caminho de individuação. Ressalta a importância dos cônjuges se tornarem conscientes de suas diferenças tipológicas para se compreenderem melhor.

Conclui que a função do terapeuta de casais é bastante variada e complexa, sendo específica para cada casal. É essencial a arte de transmitir sem rejeitar, pois lida o tempo todo com polaridades e conflitos do casal. É desejável que possa ajudar os cônjuges a viverem suas diferenças e igualdades como estímulos para a individuação de cada um e do desenvolvimento da relação do casal como um todo.

Propõe também uma classificação psicodinâmica e clínico-psicopatológico dos distúrbios vinculares de casal que possa servir como orientação prática para a identificação e discriminação de aspectos a serem trabalhados na terapia.

Os ensinamentos são múltiplos, não só para os terapeutas de casal, mas principalmente para os cônjuges que vivenciam, nesse profundo relacionamento, talvez os símbolos mais fundamentais de suas vidas.

Nairo de Souza Vargas é Professor Doutor do Departamento de Psiquiatria da Faculdade de Medicina da Universidade de São Paulo FMUSP e Membro-Fundador da Sociedade de Psicologia Analítica.

É um dos pioneiros da Terapia de Casais no Brasil, com 30 anos de experiência nesse campo e, também, um dos mais respeitados conhecedores da Psicologia Analítica de Jung em nosso meio.

1 Professor-associado e Chefe do Departamento de Psiquiatria da Faculdade de Medicina da Universidade de São Paulo - FMUSP

Endereço para correspondência: Instituto de Psiquiatria, Hospital das Clínicas da Faculdade de Medicina da Universidade de São Paulo (HC-FMUSP), Rua Ovídio Pires de Campos, 785, $3^{\circ}$ andar - CEP 05403-010 - email: zramadam@usp.br 